and 170 in Edinburgh. In September last year 593 took the examination ( 532 in London and 61 in Edinburgh).

\section{Office of Health Economics}

The address of the office of Health Economics is now 162 Regent Street, London W.1. (Telephone: 01-734 0757.)

\section{News in Brief}

Unable to find a user for Upton House, West Ham, where Lord Lister was born, the Greater London Council is withdrawing its application for a building preservation order.

People in the News

- Sir BRIAN WINDEYer, professor of radiology, London University, has been elected a fellow of the Royal Society of Arts.

- Professor K. S. KIRBY, Ph.D., has had the title of professor of cell chemistry conferred on him in respect of his post at the Institute of Cancer Research: Royal Cancer Hospital. - Professor G. G. LENNON, professor of obstetrics and gynaecology at Bristol University, has been appointed first full-time dean in the faculty of medicine in the University of Western Australia.

- Dr. J. W. ORR, professor of pathology at Birmingham University from 1948 until his retirement last September, has had the title of emeritus professor conferred on him.

- Surgeon Captain W. WILson has been appointed an Honorary Surgeon to the Queen in succession to Surgeon Captain H. L. Cleave.

\section{Grants and Awards}

The Wellcome Trust has made a grant of $£ 5,000$ to the Birmingham Medical Institute for rebinding the Institute's collection of historical books.

\section{Coming Events}

Anglo-American Medical Society (London Group) and Chelsea Arts Club.-Joint dinner meeting, "Anatomy and the Artist," 1 March, 7 p.m., Chelsea Arts Club, 143 Old Church Street, London S.W.3. Applications for tickets (12s. 6d.) to Dr. M. B. Clyne, 150 Lady Margaret Road, Southall, Middlesex.

University of Newcastle upon Tyne.Founders and Benefactors' lecture, "Some Consequences of Technical Improvement," by LORD FloREY, O.M., F.R.S., 4 March, 11.30 a.m., Physics Building, University of Newcastle upon Tyne.

British Association of Manipulative Medicine.-Symposium, "The Thoracic Spine," 12 March, Royal Army Medical College, John Islip Street, London S.W.1. Details from Honorary Secretary, B.A.M.M., 3 Arundel Terrace, Brighton 7, Sussex.

Christian Medical Fellowship.-Lister Centenary Address, "Christian Motivation in the Practice and Progress of Medicane," by Mr. Arnold S. Aldis, F.R.C.S., 16 March, 8.15 p.m., Royal Commonwealth Society's Hall (Craven Street entrance) Northumberland Avenue, London W.C.2.

\section{New Issues of Specialist Journals}

Obtainable from the Publishing Manager, B.M.A. House, Tavistock Square, London W.C.1. ABSTRACTS OF WORLD MEDICINE

The February issue (Volume 41, No. 2) is now available. Published monthly. Yearly subseription
\&6 68. U.S.A. \$18. Single number 12s. 6d.

The February issue (Volume 41, No. 2) is now available. Published mo
\&6 68. U.S.A. \$18. Single number 12s. 6d.

Institute of Urology.-Week-end course, "Recent Advances in Urology," 17-19 March. For details see advertisement on

Senior Casualty Officers in association with South Bedfordshire Division, B.M.A.-Clinical meeting, 18 March, Medical Centre, Luton and Dunstable Hospital. Fee $£$ ested in accident and emergency work. Applications to $\mathrm{Mr}$. J. F. HiNDLe, Luton and Dunstable Hospital, Luton, Bedfordshire.

For attending lectures marked a fee is charged or a ticket is required. Applications
made first to the institution concerned.

Monday, 27 February

INSTITUTB OF DeRmatology.-4.30 p.m., Dr. H Baker: Percutaneous Absorption.

Mr M. PISEASBS OF THB CHBST. -6.15 p.m., Embolism.

5NITUTB OF LARYNGOLOGY AND OTOLOGY.meeting.

ROYAL FREB Hospital. -8 p.m. Dr. R. Gibson: Reflections on Anaesthesia in Heart Disease.
ROYAL POSTGRADUATE MEDICAL SCHOOL.4 p.m., Dr. Arthur Hollman: Clinical Diagnosis Theart Disease.

Tuesday, 28 February

B.C. -2 TRLBVIsION. - 1.15 p.m., Medicine To(2) Miss Josephine Barnes: Oestrogens and Pro gestogens. (Sponsored by A.S.M.E.)

LEAB OF GENERAL PRACTITIONERS: SOUTH Maudsley Hospitai, 8.15 p.m., Pfizer lecture by, Professor H. J. Eysenck: The I.Q., its Use and Abuse.

A the Skin. GAL SOCIBTY.-At 13a Lower Grosvenor Place, London S. W. 8.45 p.m.' Dr. N. Oswald: Americas. 1.20 p.m., Dr. J. P. P. Stock: New Drugs in Royal Colibgr op Surgeons of ENGLAND.p.m., Hunterian lecture by Professor J. I. Burn Royal Statistical SoctrTy: MEDICAL SECTION.At Manson Theatre, London School of Hygiene and Tropical Medivine, S p.m., Dr. J. M. Last:
International Mobility in the Medical Profession. Wednesday, 1 March

BROOR GRNRRAL HOSPITAL.-8 p.m., Dr. I aches.

Dr Margaret B. Turner-Warwick: Rheumatoid
$\mathrm{Pr}$. Pactors in Lung Disease.

INSTrTutr of U OoLOGY.-S p.m. Mr. D. M. Bladder Tumours.

LONDON UNIVERSTTY.- Ar Senate House, 5.30 p.m. special university lecture in dietetics, nutrition, F.R.S.: Fluoride and its Hazards in Nature

Pome D J. Lane: Respiratory Pailure in Chronic ROYAL FrEB HosptTAL.-5.15 p.m., Dr. W. Brumfitt: Modern Trends in Diagnosis and Treatment of Urinary Tract Infections. (1) 10.15 a.m. medical staff round ; (2) 11.45 a.m., clinicopathological

StORB MANDBVILLB HOSPITAL. - 12.15 p.m. Dr. D. W Vere: Treatment of the Nephrotic SynWBST MIDDLBSEX HoSPITAL.-At Lecture Theatre 5 p.m.; postgraduate lecture by Mr. D. B. Bolt
and Mr. J. Scholefield: Surgical Disorders of the Pancreas.

\section{Thursday, 2 March}

ABERDEEN UNIVBRSITY FACULTY OF MEDICINB.-At Large Lecture Theatre, University Medical Build- ings, Foresterhill, 5 p.m., Lord Silkin: Abortion Law Reform.

Brook General Hospital. -8 p.m., Dr. P. Nixon: What is Intensive Care All About?

INSTITUTB OF LARYNGOLOGY AND OTOLOGY.p.m., Mr. P. H. Schurr: Auditory Nerve Tumours.

LONDON AsSOCIATION OF THB MEDICAL WOMEN's FEDERation.-At Royal Free Hospital School of Medicine, 8.30 p.m., presidential address by Pro fessor Ruth E. M. Bowden: Examiner at Large. T. ANDREWS UNIVERSITY.-At Physiology Department Lecture Theatre, Queen's College, s p.m., Rheumatoid A. Duthie.

Rheumatoid Arthris. i $W$ D. Wylie: Anaesthesia in Obstetrics. SHEPFIELD UNIVERSITY MEDICAL SOCIETY.-At Jessop Hospital, Sheffield 8 p.m., B.M.A. lecture by Dr. A Comfort: Ageing.

UNIVERSiTY COLLEG Ageing. Theatre, Gower Street, 5 p.m., lecture on bio chemistry of the red blood cell- (1) by Professor S. Rapapo

Friday, 3 March

James YearsLeY MBMorial LeCtURE. - At Roya
Society of Medicine, 5 p.m., Mr. I. G. Robin:

Society of Medicine, 5 p.m.

Kent Postgraduate Medical Centre at CanterBURY.-At Kent and Canterbury Hospital, 8.30 p.m., Dr. R. Smith: Practitioner Services in a Developing New Town. KINGSTON MEDICAL CENTRE.-At Medical Outpatients Department, Kingston Hospital, Kingstonupon-Thames 7.30 p.m., Dr. E. Rhodes : dermatological case demonstration.

LONDON SOCIETY OF FAMILY PLANNING DocTORS. At West Hall, Royal Society of Medicine, 8.15 p.m., Dr. J. R. Seale: Diagnosis and Treatmen of Venereal Diseases (illustrated).

NBWCASTLB UPON TYNB UNIVERSITY MBDICAL SocIBTY.-At New Lecture Theatre, Royal Vic toria Infirmary, Newcastle upon Tyne, 5.15 p.m. B.M.A lecture by Professor R. Warwick: Cere Royal Centres-Fact or Fiction. At Wolfson II Lecture Theatre, (1) $10.15 \mathrm{a} . \mathrm{m}$. pathological conference. ROYAL POSTGRADUATE MEDICAL SCHOOL.4 p.m., Sir Edward Wayne: Impact of Automation on Clinical Medicine.

Saturday, 4 March

Cambridge UNIVERSITY Medical School.-A Postgraduate Lecture Theatre, Addenbrooke's Hospital, 10.30 a.m., all-day symposium on Obstetrics and Gynaecology.

MIDLAND THORACIC SOCIETY.-At Birmingham Medical Institute, 3 p.m., Mr. $\$$. P. Cleland:

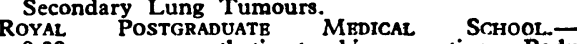
9.30 a.m. anaesthetic teaching meeting: Bod Fluids and Renal Function in Surgical Patients.

Sunday, 5 March

EDGWARE POSTGRAdUATE MEDICAL SOCIETY.-At Edgware General Hospital, 10.30 a.m. Dr. P. P.
Turner: Tropical Diseases in a Shrinking World.

Births

Dowling.-On 12 January 1967, at Boston Lying-In Hospital, Massachusetts, to Evelyn (formerly Craig) and Dr.
Michele Siobhan.

\section{Deaths}

Khan.-On 6 February 1967 , in Uganda,
Mohammed Afzal Khan, M.B., B.Ch., D.A.

\section{Correction}

We regret that in a letter from Dr. E. Jaffe (18 February, p. 428) the name of Mr. M. E. Simons was wrongly given.

All communications with regard to editorial business should be addressed to THB BDITOR, BRITISH MBDICAL JouRNAL, B.M.A. HOUSB, TAVISTOCK SQUARE, LONDON W.C.1. TELEPHONE: EUSTON 4499. TELEGRAM: Aitiology, London W.C.1. warded for publication are understood to be offered to the British Medical fournal alone unless the contrary be stated

uthors desiring REPRINTS should communicate with the Puhlishing Manager, B.M.A. House. Tavistock Square, $W . C .1$, on receipt of proofs.
ADVFRTISEMENT AND SUBSCRIPTION ORDERS should be addressed to The Manager at B.M.A. House, London, or at 415 Bourke at B.M.A. House, London, or at

MEMBERS' SURSCRIPTIONS should be sent to the SECRETARY of the British Medical Association, B.M.A. House, London, or to the Scottish Secretary, B.M.A.
Gardens, Edinburgh. 